УДК 334.72:005.95]:005.336.2

Ліпич Любов, доктор економічних наук, професор, Східноєвропейський національний університет імені Лесі Українки, кафедра економіки, безпеки та інноваційної діяльності підприємства, м. Луцьк, ORCID ID 0000-0002-9059-7271, e-mail: Lipych.Liubov@eenu.edu.ua

Хілуха Оксана, кандидат економічних наук, доцент, Східноєвропейський національний університет імені Лесі Українки, кафедра економіки, безпеки та інноваційної діяльності підприємства, м. Луцьк, ORCID ID 0000-0002-1228-7171, e-mail: Oksana.Hiluha@ eenu.edu.ua

Кушнір Мирослава, кандидат економічних наук, Український католицький університет, кафедра прикладної економіки та бізнесу, м. Львів; ORCID ID 0000-0002-4441-4278, e-mail: mlipych@ukr.net

Волинець Ірина, кандидат економічних наук, доцент, Східноєвропейський національний університет імені Лесі Українки, кафедра економіки, безпеки та інноваційної діяльності підприсмства, м. Луцьк; ORCID ID 0000-0003-2556-2109, e-mail: Irina.Volynets@eenu.edu.ua

https://doi.org/10.29038/2411-4014-2020-02-90-98

\title{
МОДЕЛІ ОЦНЮВАННЯ ЕФЕКТИВНОСТІ ПРОГРАМ РОЗВИТКУ КОМПЕТЕНТНОСТЕЙ ПРАЦІВНИКІВ
}

Компетентність персоналу є стратегічним ресурсом підприємства. Тому кадровий менеджмент має забезпечити необхідні умови для їх формування та розвитку. Підприємству, яке функціонує відповідно до принципу ефективного господарювання, слід враховувати витрати та вигоди від реалізації програм розвитку компетентностей. Це означає порівняти рівень компетентності окремих працівників до і після навчання. Результат такого аудиту дозволяє визначити ті навчальні програми, що є корисними для працівників та ефективними для підприємства.

У статті розглядаються переваги та недоліки моделей оцінювання ефективності програм розвитку компетентностей персоналу, що найчастіше використовуються підприємствами, зокрема модель Кіркпатріка та iii модифікована версія Дж. Філіпсом, модель СІРР, «метод успішних випадків» Р. Брінкерхоффа.

Для забезпечення сприйняття вітчизняною практикою зарубіжного досвіду, дослідження методології оцінювання ефективності навчання персоналу має рухатися у напрямку системної декомпозиції зарубіжних моделей та врахування особливостей національної економіки.

Ключові слова: компетентності, цілі навчання, ефективність навчальних програм, оцінювання навчальних програм, моделі оцінювання.

Липыч Любовь, доктор экономических наук, профессор, Восточноевропейский национальный университет имени Леси Украинки, кафедра экономики, безопасности и инновационной деятельности предприятия, г. Луцк

Хилуха Оксана, кандидат экономических наук, доцент, 
Восточноевропейский национальный университет имени Леси Украинки, кафедра экономики, безопасности и инновационной деятельности предприятия,

Кушнир Мирослава, кандидат экономических наук,

Украинский католический университет, кафедра прикладной экономики и бизнеса, г. Львов

Волынец Ирина, кандидат экономических наук, доцент, Восточноевропейский национальный университет имени Леси Украинки, кафедра экономики, безопасности и инновационной деятельности предприятия, г. Луцк

\section{МОДЕЛИ ОЦЕНКИ ЭФФЕКТИВНОСТИ ПРОГРАММ РАЗВИТИЯ КОМПЕТЕНТНОСТЕЙ РАБОТАЮЩИХ}

Компетентность персонала является стратегическим ресурсом предприятия. Поэтому кадровый менеджмент должен обеспечить необходимые условия для их формирования и развития. Предприятию, которое функционирует в соответствии с принципом эффективного хозяйствования, следует учитывать расходы и выгоды от реализации программ развития компетентностей. Это значит сравнивать уровень компетентности отдельных работников до и после обучения. Результат такого аудита позволяет определить те учебные программы, которые являются полезными для работников и эффективными для предприятия.

В статье рассматриваются преимущества и недостатки моделей оценки эффективности программ развития компетенций персонала, которые чаще всего используются предприятиями, в частности модель Киркпатрика и ее модифицированная версия Дж. Филлипсом, модель СІРР, «метод успешных случаев» Р. Бринкерхоффа.

Для обеспечения восприятия отечественной практикой зарубежного опыта, исследования методологии оценки эффективности обучения персонала должны двигаться в направлении системной декомпозиции зарубежных моделей с учетом особенностей национальной экономики.

Ключевые слова: компетентности, цели обучения, эффективность учебных программ, оценка учебных программ, модели оценки.

Lipych Lubov, Doctor of Economics, Professor, Lesya Ukrainka Eastern European National University, Department of Economics, Security and Innovative Activities of Enterprise, Lutsk

Khilukha Oksana, PhD in Economics, Associate Professor, Lesya Ukrainka Eastern European National University, Department of Economics, Security and Innovative Activities of Enterprise, Lutsk

Kushnir Myroslava, PhD in Economics, Ukrainian Catholic University, Department of Applied Economics and Business, Lviv

Volynets Iryna, PhD in Economics, Associate Professor, Lesya Ukrainka Eastern European National University, Department of Economics, Security and Innovative Activities of Enterprise, Lutsk 


\section{MODELS OF EFFICIENCY EVALUATION DEVELOPMENT PROGRAM OF EMPLOYEES' COMPETENCES}

Introduction. Staff competence is a strategic resource of the enterprise. Therefore, personnel management should provide the necessary conditions for their formation and development. An enterprise that operates in accordance with the principle of efficient management should consider the costs and benefits of implementing competency development programs. This means comparing the level of competence of individual employees before and after training. The result of such an audit allows us to identify training programs that are beneficial to employees and effective for the enterprise.

This purpose of the article is to systematize the experience of methods of evaluating the effectiveness of training programs for the development of employees' competences with a view to their perception of domestic practice.

Results. There are two types of competences: the necessary ones that follow from the prepared job profiles and outline the requirements for those who will perform this work in a certain workplace (position); acquired, which employees are acquired and used on the job. Therefore, the main purpose of competency development at the enterprise is to achieve a better match between the necessary and actual levels of competence. Development involves improving the already acquired competences and mastering completely new ones.

Employee competencies are developed in different ways. These are: learning through experience; use of employees as assistants, trainees; preparation in project teams; information and advice received from others (coaching, mentoring, consultations, meetings with experts); conferences, seminars, trainings taking various forms.

The diversity of approaches is explained by the fact that the development needs of each enterprise are different. In addition, the methods used must be adapted to the changing environmental conditions.

The article discusses the advantages and disadvantages of the most commonly used enterprise competence development models of performance assessment programs, including the Kirkpatrick model and its modified version by J. Phillips, the CIPP model, and R. Brinkerhoff's "case of success.

Conclusions. In order to ensure that domestic practice of foreign experience is accepted, research into the methodology of assessing the effectiveness of personnel training should move in the direction of systematic decomposition of foreign models and taking into account the peculiarities of the national economy. models.

Key words: competences, learning objectives, curriculum effectiveness, curriculum evaluation, assessment

Постановка проблеми. В сучасних умовах ведення бізнесу, навчання персоналу розглядається як дієвий інструмент впливу на рівень конкурентоспроможності підприємства, якість продукції та послуг, підвищення загального компетентнісного рівня організації тощо. В епоху економіки знань саме працівники своїми знаннями, вміннями та ставленнями визначають позицію підприємства на ринку. Оскільки компетентність персоналу $є$ стратегічним ресурсом підприємства, кадровий менеджмент має забезпечити необхідні умови для їх формування та розвитку. Тобто в персонал необхідно інвестувати, щоб покращити його якість. У той же час підприємство, як підрозділ, який дотримується принципів результативності та самофінансування, повинен уникати неефективних інвестицій, у тому числі в людський капітал, тому оцінка ефективності є важливим етапом кожного навчального процесу.

Аналіз останніх досліджень і публікацій. За останні роки проблематика оцінювання ефективності навчання персоналу набула неабиякої популярності. Коло методів і моделей, за допомогою яких організації, підприємства та установи можуть визначити доцільність розвитку персоналу. постійно розширюється від простого анкетування до використання складних статистичних процедур. Серед авторів публікацій, що присвячені більш загальним завданням оцінювання ефективності витрат у розвиток людського капіталу можна назвати таких, як: П. Ромер , Р. Лукас, Р. Нельсон, Е. Фелпс, Т. Шульц, Г. Беккер, Дж. Р. Уолт та інших.

У різних теоретичних аспектах досліджували проблематику формування та ролі людського капіталу А. Добринін, С. Дятлов, М. Критський, Н. Кошель, С. Шекшня та такі вітчизняні вчені, як В. Геєць, О. Грішнова, Г. Свтушенко, С. Лібанова, В. Куценко, С. Писаренко, Л. Шевчук та інші.

У цілому, наукова література пропонує велику кількість результатів досліджень проблем оцінювання ефективності навчання персоналу. Разом із цим, в більшості наукових публікацій лише дискутують навколо тематики дослідження або пропонують неперевірений часто описовий матеріал, 
у якому моделі і методи лише ідентифікуються, але рідко забезпечується їх доведення до практичних рекомендацій.

Постановка завдання. Метою статті $є$ систематизація досвіду щодо методів оцінювання ефективності навчальних програм розвитку компетентностей працівників 3 метою їх сприйняття вітчизняною практикою.

Виклад основного матеріалу дослідження. Виокремлюють два види компетентностей пов'язаних з роботою працівника на підприємстві. Перш за все, це необхідні компетентності, які випливають із підготовлених профілів роботи та окреслюють вимоги до тих, хто буде виконувати цю роботу на певному робочому місці (посаді). По-друге, аналізуються компетентності, які працівники придбали та застосовують на роботі. Тому головною метою розвитку компетентностей на підприємстві $є$ досягнення кращої відповідності між необхідним та фактичним рівнем компетентностей. Розвиток передбачає як удосконалення вже набутих компетентностей, так i оволодіння абсолютно новими. Більше того, на підприємствах, що використовують в управлінні людськими ресурсами компетентнісний підхід, акцент робиться на розвитку компетентностей працівників на основі визначених ключових компетентностей компанії. Таким чином реалізується концепція стратегічного інвестування в людський капітал, а конкретні напрями вдосконалення та набуття нових компетентностей узгоджуються 3 довгостроковими цілями, вираженими у вигляді стратегій.

Розвиток компетентностей - це процес. Перш ніж працівник осягне необхідні компетентності, йому притаманна так звана неусвідомлена некомпетентність. Це означає, що він не усвідомлює необхідності набуття конкретних знань, умінь та навиків, необхідних для належного виконання роботи. Завдання тоді виконуються на рутинному та рефлексивному рівні - спосіб виконання роботи такий самий або дуже схожий незалежно від ії контексту. Ключовим моментом у розвитку компетентності $є$ перехід від першого рівня до другого, коли відбувається усвідомлення факту некомпетентності. Це називається пізнавальна стадія, яка характеризується прийняттям незнання. Важливо, що в той же час наступає розуміння необхідності придбання або поповнення певного ресурсу вмінь. Процес розвитку веде послідовно до усвідомленої компетентності. Це етап, на якому уже здобуті теоретичні знання та практичні аспекти його використання, але виконання роботи вимагає постійного удосконалення. Працівник починає втілювати в життя те, що знає, але ще не працює на повну силу, оскільки не набув достатньої майстерності. На етапі несвідомої компетентності виконувати роботу ефективно можна лише коли вона відповідає ситуаційному контексту. У випадку складних завдань, що вимагають реагування на суперечливу інформацію, крім навиків, що забезпечують виконання певної діяльності звичним способом, компетентний працівник демонструє постійну креативність.

Компетентності працівників можна розвивати різними способами. Серед найпопулярніших такі:

- навчання через досвід;

- використання працівників у ролі асистентів, стажерів;

- підготовка в проектних групах;

- інформація та поради, отримані від інших (коучинг, наставництво, консультації, зустрічі 3 експертами);

- конференції, семінари;

- тренінги, що приймають різноманітні форми.

Різноманітність підходів пояснюється тим, що потреби в розвитку на кожному підприємстві різні, тому універсальної схему процесу розвитку компетентностей не існує. Крім того, використовувані методи повинні бути адаптовані до мінливих умов зовнішнього середовища.

Розвиток людського капіталу, що означає якісні зміни трудових ресурсів, покращує конкурентну позицію та підвищує ринкову вартість підприємства. На рівні підприємства розвиток людського капіталу відбувається, в основному, завдяки навчанню. Навчання вимагає значних витрат, крім того, інвестиції в людський капітал не дають негайного їх повернення (ці витрати окупляться через кілька місяців або навіть років). Тому підприємство повинно здійснювати економічні розрахунки при плануванні програм розвитку компетентностей працівників.

Навчання можна вважати ефективним, коли працівники підприємства набувають визначених компетентностей і пов'язані з цим переваги перевищують витрати на навчання. Ефективне навчання 
компетентностей приносить результат у формі набуття учасниками прийомів (технік), що були предметом занять, i в подальшій перспективі їх застосування на практиці та розвитку навичок при користуванні ними. Крім того, що після навчання працівники набувають конкретних знань про нові способи роботи, щоб навчальний процес був ефективним, працівники повинні використовувати набуті знання на практиці і тим самим демонструвати конкретні навички та зміну ставлення до роботи.

Кожне підприємство, яке здійснює навчальну діяльність щодо своїх працівників, є "інвестором", що несе певні витрати на збільшення ресурсу компетентності. Цьому виду діяльності, як будь-якій іншій інвестиційній діяльності, загрожують невдачі. Основний інструмент, який використовується для їх усунення, - це перевірити ефективність навчання, завдяки чому можна вносити корективи у навчальний процес. Основна проблема полягає у створенні надійної системи оцінювання ефективності тренінгу, яка б забезпечувала осіб, які приймають рішення, потрібною інформацією.

Спроби класифікації та систематизованого опису моделей оцінки ефективності навчання представляє табл. 1, куди включено десять моделей оцінки розвитку людських ресурсів [1].

Таблиия 1

Систематизація методів оцінювання ефективності навчання персоналу

\begin{tabular}{|c|c|}
\hline Автори & Схеми оцінювання за напрямами \\
\hline 1. Kirkpatrick [2] & Чотири рівні: реакція, навчання, поведінка та результати \\
\hline $\begin{array}{l}\text { 2. CIPP, Stufflebeama } \\
\text { [3] }\end{array}$ & Чотири рівні: контекст, вхід, процес, ефект \\
\hline 3. CIRO, Warr et al. [4] & Чотири рівні: контекст, внесок, реакція та результати \\
\hline 4. Brinkerhoff [5] & $\begin{array}{l}\text { Шість етапів: постановка задач, планування програми, реалізація } \\
\text { програми, поточний результат, кінцевий результат, вплив та } \\
\text { значення }\end{array}$ \\
\hline $\begin{array}{l}\text { 5. Systems approach, } \\
\text { Bushnell [6] }\end{array}$ & Чотири рівні: внесок, процес, продуктивність та наслідки. \\
\hline $\begin{array}{l}\text { 6. Kraiger, Ford and } \\
\text { Salas [7] }\end{array}$ & $\begin{array}{l}\text { Три види результату від навчання: когнітивний, базисні навики, } \\
\text { емоційний. }\end{array}$ \\
\hline $\begin{array}{l}\text { 7. Kaufman, Keller and } \\
\text { Watkins [8] }\end{array}$ & $\begin{array}{l}\text { П'ять рівнів: пристосування і реакція, оволодіння, застосування, } \\
\text { продуктивність підприємства, соціальні наслідки. }\end{array}$ \\
\hline 8. Holton [9] & $\begin{array}{l}\text { П’ять рівнів: вплив, елемент мотивації, зовнішні чинники, } \\
\text { наслідки, пристосованість }\end{array}$ \\
\hline 9. Phillips [10] & $\begin{array}{l}\text { П'ять рівнів: Реакція і планування дій, навчання, практичне } \\
\text { застосування знань на робочому місці, результати, повернення від } \\
\text { інвестицій. }\end{array}$ \\
\hline $\begin{array}{l}\text { 10. Results } \\
\text { Swanson and } \\
{[11]}\end{array}$ & $\begin{array}{l}\text { Чотири рівні: параметри «виходу» системи й фінансові результати, } \\
\text { досягнуті рівні знань і досвіду, та реакції учасників і зацікавлених } \\
\text { сторін }\end{array}$ \\
\hline
\end{tabular}
Джерело: [1] 14]:

На практиці найчастіше використовуються два підходи до оцінки ефективності навчання $[12,13$,

1. Цільове оцінювання, де оцінка результатів навчання проводиться 3 точки зору раніше прийнятих цілей навчання. Навчання вважається ефективним, якщо цілі були досягнуті - працівники розвинули або набули конкретних компетентностей. Набуття додаткових знань чи навичок, які не були визначені як пріоритетні, не впливає на оцінку ефективності навчання. На цьому підході базується одна 3 найпопулярніших моделей оцінювання модель Д Кіркпатріка (D. Kirkpatricka) або іï модифікована версія так звана модель Філіпса (Phillips).

2. Систематичне оцінювання. Цей підхід враховує більш широкий контекст навчального процесу. Оцінка ефективності починається на етапі встановлення навчальних цілей та вибору методів і відбувається протягом усього навчального процесу. У рамках цього підходу найуживанішими є модель запропонована Стафлебеамом (Stufflebeam) так звана модель CIPP та модель Р. Брінкерхоффа (Brinkerhoff, R.O. ) - «метод успішних випадків». 
Розглянемо більш детально сутність цих моделей.

Модель Кіркпатріка розроблена як цільова оцінка. У цій моделі аналіз ефективності проекту навчання проводиться на чотирьох рівнях:

1. Рівень реакції (reaction, response), на якому збираються суб'єктивні дані (думки та оцінки) рівня задоволеності учасників тренінгу. Визначення зазвичай робиться відразу після навчання. Інструментом, який найчастіше використовується для цього, $є$ анкетування.

2. Рівень навчання (learning), на якому, використовуючи спеціальні тести, істинно-хибні тести, відкриті тести (незакінчені речення) тощо оцінюють рівень досягнення дидактичних цілей навчання.

3. Рівень поведінки (behaviour, performance),, на якому визначається вплив навчальних програм на зміну поведінки на робочому місці. На цьому етапі найчастіше використовуються такі методи: експериментальний, метод $360^{\circ}$, листи оцінювання працівників, аналіз документів.

4. Рівень результатів (results), на якому ідентифікуються досягнення учасників тренінгу після його закінчення, що вплинули на результати роботи всієї організації. Під час цього етапу проводиться оцінка ефективності навчальних програм за посередництвом показників роботи підприємства в інших сферах (виробництво, ринок, фінанси).

Перші два рівні оцінюють індивідуальні досягнення (особисті), тоді як два інші стосуються ефективності діяльності підприємства. 3 часу публікації моделі (1959р.) через іiі простоту та зрозумілість вона широко використовується під час оцінювання програм навчання персоналу. Хоча модель дуже грунтовно представлена у спеціальній літературі, підприємства не завжди реалізовували усі чотири рівні. Лише у деяких випадках увага приділялася поведінковим результатам. Наприклад, аналіз досліджень, опублікованих і неопублікованих, які оцінювали ефективність навчання, що проводилося у формі тренінгів з моделювання поведінки, показав, що у 52 випадках вимірювалося ставлення до навчання, у 46 - отримані знання, у 66 - виробнича поведінка, і жодне не ставило завдання визначити результати у бізнесі [15].

У 1996 році модель Кіркпатріка була доповнена. Джек Філіпс запропоновано п'ятий рівень коефіцієнт прибутковості інвестицій (ROI) та співвідношення вигод i витрат BCR (benefits costs ratio). Щодо навчання, рентабельність інвестицій розраховується таким чином [10, с. 151]:

$$
R O I=\frac{\text { доходи від навчання - виграти на реалізацію навчальної програми }}{\text { витрати на реалізацію навчальної програми }},
$$

a BCR так:

$$
B C R=\frac{\text { сума доходів від інвестуван ня в навчання }}{\text { обсяг інвестицій }},
$$

Основне питання полягає у відповіді на питання чи вартість результатів навчання перевищує витрати на його реалізацію. Негативна відповідь може бути важливішою для загальної оцінки навчального процесу, ніж позитивний результат чотирьох інших рівнів традиційної моделі Кіркпатріка. Тому оцінка ефективності розглядається як надзвичайно важливий етап в реалізації програм розвитку компетентностей, бо визначає, чи йде тренінг попереду потреб підприємства та чи ефективно використовуються наявні ресурси.

Оцінювання навчання також повинно враховувати не тільки матеріальні доходи та витрати, але й нематеріальні. Нематеріальні переваги включають, наприклад, збільшення мотивації працівників та їх бажання виконувати завдання краще, ідентифікація себе з підприємством, підвищення рівня комунікування між членами колективу, краще розуміння та прийняття організаційних змін тощо.

Крім моделі Кіркпартика та іiї доповнення у вигляді моделі Філліпса для оцінки ефективності навчання також використовується модель CIPP (context, imput, process, product - контекст, вхід, процес, ефект), розроблена

Д.Л. Стафлебеамом (Stufflebeama). За його припущеннями, оцінювачі прагнуть визначити потреби, виявити проблеми, запропонувати альтернативні рішення, які менеджери змогли б застосувати і які призвели б до досягнення встановлених цілей. 
У цій моделі оцінюється ефективність розвитку компетентностей у чотирьох напрямах. Перший - це контекст. Йдеться про збір інформації про поточну ситуацію на підприємстві, про проблеми працівників, неефективні заходи та процедури. Таким чином приймається рішення про освітні потреби та встановлюються цілі навчальних програм.

Далі в наступному напрямі аналізу (внесок) збираються дані для полегшення прийняття рішень щодо форми навчання, а також для розрахунку витрат, що вимагає навчання. Згодом на третьому напрямі (процес) генеруються оцінки та думки учасників тренінгу з методичних та організаційних питань тренінгової програми. Оцінюється реалізація навчання. Завершує модель етап продукту, метою якого $\epsilon$ збирання інформації про фактичні наслідки проведених тренінгів розвитку компетентностей, при цьому оцінюються безпосередні, опосередковані та довгострокові результати [3].

Підводячи підсумок, можна зауважити, що модель СIPР дає можливість розглянути ефективність програми розвитку компетентностей в цілісному контексті, оскільки оцінка враховує передбачувані цілі навчання, адекватність обраних методів, задоволеність учасників та реально досягнуті результати.

Ще один науковець Р. Брінкерхофф представив модель, яку він називає «методом успішних випадків» [16]. Метод передбачає вивчення успішних і невдалих елементів навчальних програм. Потім ця інформація використовується для документування ефектів і визначення чинників, які сприяють або перешкоджають їх збільшенню. Вона також надає дані про вплив навчання на результати діяльності підприємства.

Представлені моделі оцінювання ефективності програм розвитку компетентностей мають на меті допомогти керівникам оцінити результати навчальної діяльності. Однак у практичній діяльності існує багато проблем, пов'язаних із правильно проведеною діагностикою ефективності тренінгів. До найбільш серйозних можна віднести [17]:

1. Часова перспектива оцінювання. Підприємці, працівники, менеджери персоналу чи самі спікери найчастіше оцінюють ефективність навчання лише після його закінчення і обмежуються іспитом, відгуками учасників або перевіркою набутих ними знань. Тим часом, належна оцінка ефективності навчання повинна відбуватися в різні моменти часу - до запуску програми, протягом іiі тривалості, після її завершення та під час виконання працівником щоденних професійних обов'язків. Тільки 3 цієї точки зору можна адекватно оцінити, чи забезпечить програма навчання реалізацію цілей та чи, як наслідок, працівники змінили свою щоденна поведінка, щоб їх діяльність була ефективнішою.

2. Недостатня об'єктивність оцінки. Кожен учасник, зацікавлений у навчальній програмі, має свої цілі, і тому по-різному оцінює іiі ефективності. Наприклад, для працівника навчання буде ефективним, коли воно забезпечує здобуття конкретних практичних навичок, які можна використовувати в повсякденній роботі. Для інвесторів у розвиток персоналу ефективне навчання це підвищення результатів діяльності підприємства. Керівник структурного підрозділу, у свою чергу, може вирішити, що реалізація навчальних цілей повинна бути пов'язана з більшою комунікативність колективу. Спікер визначить навчання як ефективне, коли виконає запланований графік занять. 3 огляду на вищезазначене, важливо, щоб кінцевий результат оцінки навчальної програми складався 3 думок усіх зацікавлених сторін, тоді ймовірність суб'єктивності судження зводиться до мінімуму.

3. Скрупульозність оцінки. Моделі Kirkpatrick, Phillips чи CIPP - це моделі багатоетапного оцінювання навчальних програм. Скрупульозний аналіз означає, що оцінювання вимагає як певного часу, так і набуття навичок використання схеми оцінювання. Тому на практиці оцінювання часто виконується фрагментарно. Замість використання чотирьох рівнів оцінки ефективності як частини моделі Кіркпатріка, зацікавлені сторони обмежуються опитуванням рівня задоволеності навчанням. Таким чином скорочується час оцінки, проте, на жаль, за рахунок отримання точної інформації.

4. Складність визначення реальних наслідків навчання. Слід пам'ятати, що чітке визначення рентабельності інвестицій під час тренінгу є досить проблематичним, оскільки в кожному випадку воно вимагає посилання на конкретні показники наприклад, кількість виготовленої чи реалізованої продукції, валовий дохід, плинність персоналу тощо. Проблемою також є визначення реального впливу на функціонування підприємства збільшення знань, умінь і навичок чи зміни ставлення 
слухачів до праці. Це пов'язано з тим, що на кожну сферу діяльності підприємства впливає одночасно безліч змінних і виділення однієї є складним завданням.

Представлені чотири проблеми не вичерпують перелік, вони лише сигналізують про складність процесу оцінки ефективності навчальних програм. Однак, усвідомлення існування проблем не повинно, перешкоджати проведенню оцінки, а лише застерігати про можливі помилки.

Висновки і перспектива подальших досліджень. У роботі представлена сутність розвитку потенціалу працівників. Акцентовано увагу на питанні ефективності навчання та представлені моделі оцінки результатів впроваджених навчальних програм.

Підсумовуючи міркування щодо представлених підходів до оцінювання навчання, можна сказати, що концепція моделі Кіркпатріка базується на цілях підприємства, які можуть корелювати від суто технічних до корпоративної стратегії підприємства. Слабкою позицією цієї моделі є те, що вона не визначає заходів, необхідних для досягнення намічених цілей, не містить способів використання отриманих результатів оцінки для вдосконалення програми навчання. 3 вищезазначених причин багато підприємств не використовує всю модель, зосереджує увагу лише на перших етапах.

У той же час розробка моделі Кіркпатріка дала можливість Дж. Філіпсу оцінити ефективність розвитку компетентності з точки зору рентабельності. Для цього він використав фінансовий показник повернення інвестицій ROI та співвідношення витрат і вигод BCR.

Системний підхід до оцінки, який використовується в моделі СІРР,видається кориснішим при розгляді загального контексту програм для підвищення конкретних компетентностей працівників. 3 іншого боку проблема виникає через відсутністю бажаного рівня деталізації при проведені аналізу, а системна оцінка не показує кореляції між навчанням та оцінкою розвитку компетентності.

«Метод успішних випадків» Р. Брінкерхоффа передбачає вивчення успішних і невдалих складових навчальних програм та надає дані про вплив навчання на результати діяльності підприємства.

Для забезпечення сприйняття вітчизняною практикою зарубіжного досвіду, дослідження методології оцінювання ефективності навчання персоналу має рухатися у напрямку системної декомпозиції зарубіжних моделей та врахування особливостей національної економіки.

\section{Джерела та література}

1. DeSimone R. L., Werner J. M., Harris D. M. Human resource development. Mason, South Western, 2003.

2. Kirkpatrick D. Revisiting Kirkpatrick’s four-level-model. Training \& Development, 1996. № 1. P. 54-57.

3. Stufflebeam D. L. Evaluation perspectives and procedures, w: Evaluation in Education, ed. W. J. Popham, McCutchan. Berkley. 1974.

4. Warr P., Bird M. \& Rackham N. Evaluation of management training. London: Gower Press. 1970.

5. Brinkerhoff R. O. Increasing impact of training investments: an evaluation strategy for building organizational learning capability. Industrial and Commercial Training. 2006. № 6. V. 38. P. 302-307.

6. Bushnell D. S. Input, process, output: A model for evaluating training. Training and Development Journal. 1990. № 44 (3). P. 41-43.

7. Kraiger K., Ford J. K. \& Salas E. Application of cognitive, skill-based, and affective theories of learning outcomes to new methods of training evaluation. Journal of Applied Psychology. URL: www.apa (retrieved: 24.04.2020).

8. Kaufman R., Keller J. and Watkins R. What Works and What Doesn't: Evaluation Beyond Kirkpatrick. Performance and Instruction. 1996. № 35 (2). P. 8-12.

9. Holton E. F. The flawed four-level evaluation model. Human Resource Development Quarterly. 1996. № 7 (1) P. 5-21.

10. Phillips J.J. ROI: the search for Best Practices. Training and Development. 1996. P. 42-47.

11. Swanson R. A., Holton E. F. Results: How to assess performance, learning and perceptions in organizations. San Francisco CA; Berrett Kochler. 1999.

12. Bramley P. Evaluating training effectiveness. McGraw-Hill, Maidenhead. 1996.

13. Eseryel D. Approaches to Evaluation of Training: Theory \& Practice. Educational Technology \& Society. 2002. № 5 (2).

14. Worthen B. R., Sanders J. R. Educational evaluation. Longman, New York. 1987.

15. Taylor P. J., D. F. Russ-Eft and D. W. L. Chan. A meta-analytic review of behavior modeling training. Journal of Applied Psychology. 2005. № 90. P. 692-709. 
16. Brinkerhoff R. O. Increasing impact of training investments: an evaluation strategy for building organizational learning capability. Industrial and Commercial Training. 2006. № 6. V. 38. P. 302-307.

17. Wieczorek-Szymańska A. Problematyka oceny efektywności programow rozwoju kompetencji pracownikow. Studia i prace wydziału nauk ekonomicznych i zarządzania. 2011. № 24. S. 205-207.

\section{References}

1. DeSimone R. L., Werner J. M., Harris D. M. (2003). Human resource development. Mason, South Western. [in English].

2. Kirkpatrick D. (1996). Revisiting Kirkpatrick’s four-level-model. Training \& Development. № 1. P. 54-57. [in English].

3. Stufflebeam D. L. (1974). Evaluation perspectives and procedures, w: Evaluation in Education, ed. W. J. Popham, McCutchan. Berkley. [in English].

4. Warr P., Bird M. \& Rackham N. (1970). Evaluation of management training. London: Gower Press. [in English].

5. Brinkerhoff R. O. (2006). Increasing impact of training investments: an evaluation strategy for building organizational learning capability. Industrial and Commercial Training. № 6. V. 38. P. 302-307. [in English].

6. Bushnell D. S. (1990). Input, process, output: A model for evaluating training. Training and Development Journal. № 44 (3). P. 41-43. [in English].

7. Kraiger K., Ford J. K. \& Salas E. Application of cognitive, skill-based, and affective theories of learning outcomes to new methods of training evaluation. Journal of Applied Psychology. URL: www.apa (retrieved: 24.04.2020). [in English].

8. Kaufman R., Keller J. and Watkins R. (1996). What Works and What Doesn't: Evaluation Beyond Kirkpatrick. Performance and Instruction. № 35 (2). P. 8-12. [in English].

9. Holton E. F. (1996). The flawed four-level evaluation model. Human Resource Development Quarterly. № 7 (1). P. 5-21. [in English].

10. Phillips J.J. (1996). ROI: the search for Best Practices. Training and Development. P. 42-47. [in English].

11. Swanson R. A., Holton E. F. (1999). Results: How to assess performance, learning and perceptions in organizations. San Francisco CA; Berrett Kochler. [in English].

12. Bramley P. (1996). Evaluating training effectiveness. McGraw-Hill, Maidenhead. [in English].

13. Eseryel D. (2002). Approaches to Evaluation of Training: Theory \& Practice. Educational Technology \& Society. № 5 (2). [in English].

14. Worthen B. R., Sanders J. R. (1987). Educational evaluation. Longman, New York. [in English].

15. Taylor P. J., D. F. Russ-Eft and D. W. L. Chan. (2005). A meta-analytic review of behavior modeling training. Journal of Applied Psychology. № 90. P. 692-709. [in English].

16. Brinkerhoff R. O. (2006). Increasing impact of training investments: an evaluation strategy for building organizational learning capability. Industrial and Commercial Training. № 6. V. 38. P. 302-307. [in English].

17. Wieczorek-Szymańska A. (2011). Problematyka oceny efektywności programow rozwoju kompetencji pracownikow. Studia i prace wydziału nauk ekonomicznych i zarządzania. № 24. S. 205-207. [in Polish].

Стаття надійшла до редакції 05.05.2020 p. 